\title{
ANALISIS PERUBAHAN GARIS PANTAI DI WILAYAH PANTAI BARAT KABUPATEN TANAH LAUT KALIMANTAN SELATAN
}

\section{ANALYSIS OF SHORELINE CHANGE IN WEST COAST AREA OF TANAH LAUT DISTRICT SOUTH KALIMANTAN}

\author{
Darmiati $^{1}$, I Wayan Nurjaya ${ }^{2}$, \& Agus S. Atmadipoera ${ }^{2 *}$ \\ ${ }^{1}$ Program Studi Teknologi Kelautan, FPIK, Sekolah Pascasarjana IPB, \\ Bogor 16680, Indonesia \\ ${ }^{2}$ Departemen Ilmu dan Teknologi Kelautan, FPIK-IPB, Bogor, 16680, Indonesia \\ *E-mail: atmadipoera_itk@ipb.ac.id
}

\begin{abstract}
Shoreline changes are processes that occur due to the influence of coastal conditions in seeking the balance of the impacts that occur from natural factors and human activities. The coastal area of Tanah Laut Regency South Kalimantan covers along the west coast and south coast region. Physically this region is influenced by oceanographic dynamics of the Java Sea and the Barito River runoff that changes seasonally. This study aims to determine the shoreline changes of the West Coast area of Tanah Laut Regency, South Kalimantan. The data used are Landsat 8 imagery acquisition in 2016 to describe the current condition and Landsat imagery 7 the acquisition year 2003 as an initial condition. Data were analyzed to determine the shoreline changes that had accretion or abrasion of the coastline. The results showed that the coastline of the West Coast area of Tanah Laut regency experienced changes in abrasion and accretion conditions. Overall the coastal areas of Tanah Laut Regency dominated accretion than abrasion. In particular, cell numbers 3 and 4 have been recorded as abrasion areas; even the cells are near the estuary of Barito River.
\end{abstract}

Keywords: abrasion and accretion, coastline changes, Landsat imagery, Tanah Laut Regency

\begin{abstract}
ABSTRAK
Perubahan garis pantai merupakan proses yang terjadi akibat adanya pengaruh dari kondisi pantai dalam mencapai keseimbangan terhadap dampak yang terjadi dari faktor alami dan kegiatan manusia. Secara geografis, wilayah pesisir pantai Kabupaten Tanah Laut Kalimantan Selatan mencakup dua wilayah yang berada di tepi barat dan tepi selatan. Secara fisik wilayah ini dipengaruhi oleh dinamika oseanografi dari perairan Laut Jawa serta aliran Sungai Barito yang bervariasi secara musiman. Penelitian ini bertujuan untuk menganalisis perubahan garis pantai di wilayah pesisir Pantai Barat Kabupaten Tanah Laut, Kalimantan Selatan. Data yang digunakan adalah citra Landsat 8 tahun 2016 untuk menggambarkan kondisi terkini dan citra Landsat 7 tahun 2003 sebagai kondisi awal. Citra tersebut dianalisis untuk dipetakan perubahan garis pantai yang mengalami akresi atau abrasi. Hasil penelitan menunjukkan bahwa garis pantai wilayah studi mengalami perubahan, dimana sebagian telah mengalami abrasi dan sebagian garis pantai telah mengalami akresi. Secara keseluruhan garis pantai wilayah Pantai Barat Kabupaten Tanah Laut dominan mengalami akresi dibandingkan abrasi karena adanya proses sedimentasi tinggi dari sungai Barito. Tetapi, di segmen garis pantai sel 3 dan 4 telah mengalami abrasi, meskipun area ini dekat dengan estuari Sungai Barito.
\end{abstract}

Kata kunci: abrasi dan akresi, citra Landsat, Kabupaten Tanah Laut, perubahan garis pantai

\section{PENDAHULUAN}

Pantai adalah kawasan yang bersifat dinamis karena merupakan tempat pertemuan dan interaksi antara darat, laut, dan udara. Pantai selalu memiliki penyesuaian yang terus menerus menuju keseimbangan alami terhadap dampak yang terjadi sehingga mempengaruhi perubahan garis pantai. Perubahan garis pantai merupakan salah satu 
proses yang cukup dinamis dalam dinamika pesisir, seperti halnya juga perubahan delta dan batimetri perairan pantai (Mills et al., 2005). Menurut Arief et al. (2011) perubahan garis pantai adalah suatu proses tanpa henti (terus-menerus) melalui berbagai proses alami di pantai yang meliputi pergerakan sedimen, arus menyusur pantai (longshore current), aksi gelombang permukaan laut dan penggunaan lahan.

Perubahan garis pantai dapat disebabkan oleh faktor alami maupun antropogenik (manusia). Faktor alami berupa sedimentasi, abrasi, pemadatan sedimen pantai, kenaikan muka laut dan kondisi geologi. Faktor manusia berupa penanggulan pantai, penggalian sedimen pantai, penimbunan pantai, pembabatan tumbuhan pelindung pantai, pembuatan kanal banjir dan pengaturan pola daerah aliran sungai (Sudarsono, 2011). Perubahan garis pantai dapat terjadi dari waktu ke waktu dalam skala musiman maupun tahunan, tergantung pada daya tahan kondisi pantai dalam bentuk topografi, batuan dan sifat-sifatnya dengan gelombang laut, pasang surut (pasut), dan angin (Opa, 2011).

Wilayah pesisir Kabupaten Tanah Laut berada di bagian selatan dari Kalimantan dan berhadapan langsung dengan Laut Jawa. Secara fisik wilayah ini dipengaruhi oleh dinamika oseanografi (seperti pasang surut, gelombang dan arus) dari perairan Laut Jawa serta aliran sungai Barito yang berubah pada setiap musim. Kabupaten Tanah Laut terbagi menjadi dua wilayah yaitu pesisir Pantai Barat dan Selatan yang menjorok ke arah laut. Pada umumnya gelombang laut di perairan Kabupaten Tanah Laut dalam musim Barat merambat dari arah barat laut, barat, barat daya, sedangkan dalam musim Timur berasal dari selatan dan tenggara. Selain itu, pemanfaatan dan pengembangan kawasan pesisir pantai Tanah Laut cenderung meningkat setiap tahunnya seperti sebagai areal pelabuhan, transportasi laut, perkebunan, pertanian, pemukiman dan perdagangan (Iriadenta, 2013).

Peningkatan pemanfaatan areal pantai pada kawasan ini berdampak pada terganggunya ekosistem dan keseimbangan pola hidrodinamika pantai seperti transformasi gelombang dan keseimbangan pantai yang meliputi kenaikan muka air laut, terjadinya perubahan garis pantai dengan meningkatnya erosi dan sedimentasi, perubahan pola cuaca dan iklim, kenaikan suhu permukaan air laut. Sardiyatmo et al. (2013) menyatakan perubahan garis pantai memberikan dampak apabila abrasi telah mengakibatkan kerusakan prasarana dan sarana yang ada di pantai, demikian juga halnya dengan akresi akan berakibat pada tertutupnya muara sungai sehingga menimbulkan banjir.

Khususnya di Kabupaten Tanah Laut pada kawasan pesisir dan pantai barat, selain dipengaruhi oleh aktivitas manusia juga dipengaruhi oleh limpasan Sungai Barito dan Sungai Kapuas. Kawasan pemukiman dan pantai di daerah ini banyak yang mengalami abrasi, sedimentasi di alur transportasi sungai, serta kondisi cuaca yang ekstrim. Pada bagian pantai ini terutama pada musim barat, ketika terjadi pasang tertinggi, limpasan air telah memasuki kawasan pemukiman. Jika bersamaan dengan curah hujan yang tinggi, maka sering terjadi banjir. Selama ini banyak hal yang telah dilakukan oleh pemerintah dan masyarakat untuk mengurangi dampak perubahan garis pantai di kawasan ini seperti penanaman mangrove, pembuatan bangunan pantai, akan tetapi kegiatan tersebut masih belum efektif dalam meredam perubahan garis pantai (Iriadenta, 2013).

Penentuan perubahan garis pantai dapat dilakukan baik secara langsung in situ dengan pengukuran lapangan, maupun dengan menggunakan data dari citra satelit. Penggunaan data citra satelit untuk monitoring perubahan garis pantai memiliki beberapa keuntungan, yaitu mampu memonitor cakupan wilayah yang luas (Kasim, 2012). Oleh karena itu penelitian ini 
bertujuan untuk menganalisis perubahan garis pantai di Kabupaten Tanah Laut bagian barat yang mendapat pengaruh besar dari limpasan Sungai Kapuas dan Sungai Barito dengan menggunakan data citra satelit Landsat.

\section{METODE PENELITIAN}

\subsection{Lokasi Penelitian}

Penelitian berlokasi di pesisir Pantai Barat Kabupaten Tanah Laut mulai dari muara Sungai Kapuas di Utara, muara Sungai Barito sampai sebagian tanjung wilayah selatan pesisir Kabupaten Tanah Laut, seperti terlihat pada Figure 1 yang bertanda kotak merah. Penentuan lokasi penelitian ditetapkan berdasarkan wilayah pesisir yang wilayah pantainya lebih mendapatkan pengaruh dari daerah sungai. Volume sedimen yang besar dari sungai Barito, bentang lahan yang landai, dan adanya arus dan gelombang laut mengakibatkan adanya pengendapan sedimen yang intensif di laut pesisir Pantai Barat yang berpengaruh pada perubahan garis pantai (Iriadenta, 2013).

\subsection{Data Citra}

Data yang digunakan dalam penelitian adalah data citra satelit Landsat 7 (tahun 2003) sebagai referensi kondisi garis pantai tahun 2003, dan citra Landat 8 sebagai acuan kondisi garis pantai tahun 2016. Data citra Landsat tersebut dapat diakses di alamat web http://earthexplorer.usgs.gov. Data pendukung penelitian ini berupa data prediksi pasang surut dan data batimetri

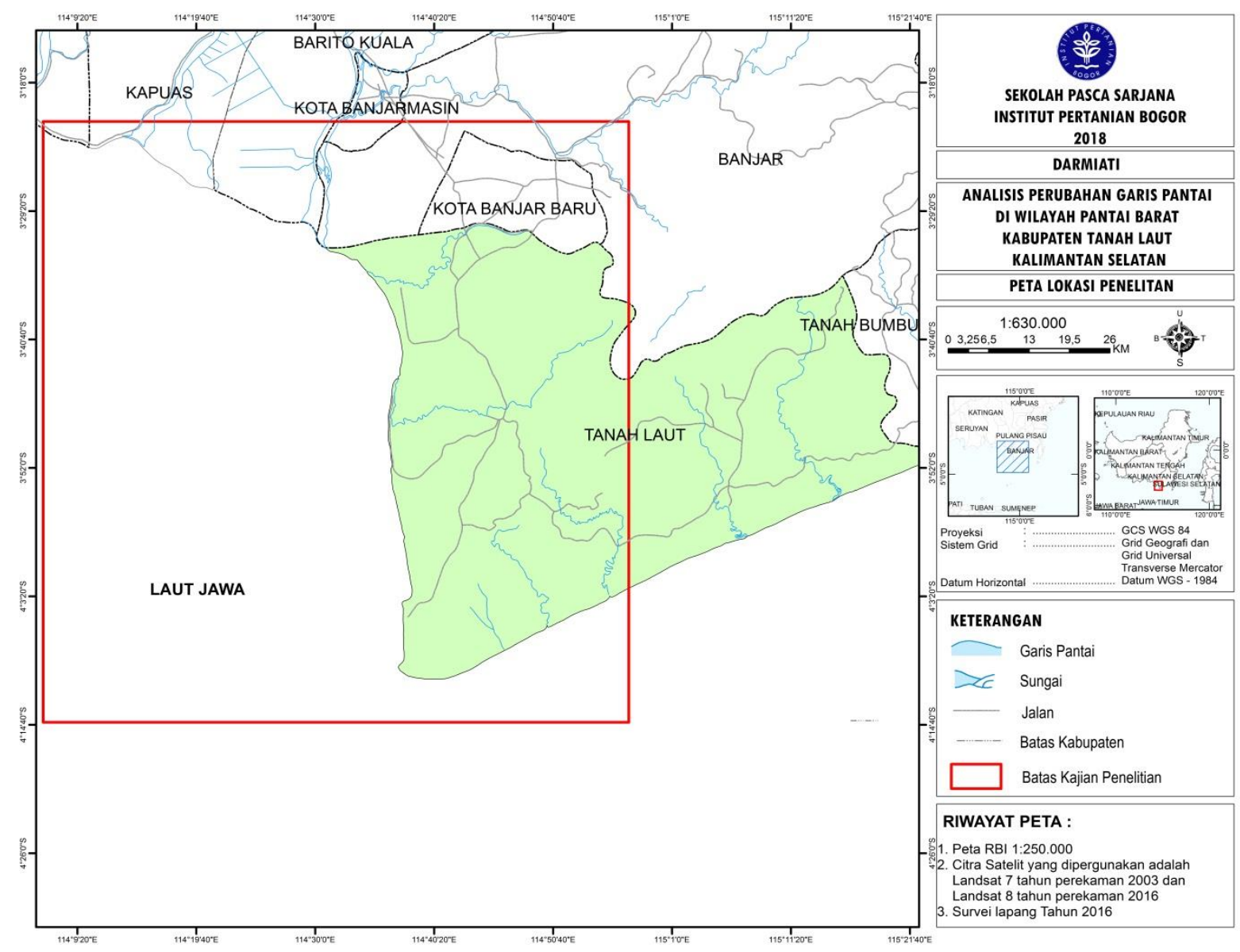

Figure 1. The study area of shoreline changes analysis on the western coast of Tanah Laut Regency, South Kalimantan Province. 
tahun 2005 dari peta batimetri Pusat Hidrografi dan Oseanografi TNI Angkatan Laut (PUSHIDROSAL) untuk menghitung kemiringan pantai pada tiap profil yang ditentukan, serta untuk pengoreksian citra terhadap kondisi genangan pasang surut.

\subsection{Analisis Data}

Pengolahan dan analisis data mencakup beberapa tahapan, seperti koreksi citra, dan pemotongan citra. Pengolahan citra dilakukan dengan menggunakan program Arc GIS. Tahapan pengolahan data citra terdiri dari koreksi geometrik, pemotongan citra, analisis citra untuk perubahan garis pantai, koreksi garis pantai hasil citra terhadap pasang surut dan tumpang-susun.

Koreksi geometrik dimaksudkan untuk mengoreksi distorsi spasial objek pada citra sehingga posisi objek yang terekam sesuai dengan koordinat di lapangan. Data raster umumnya ditampilkan dalam bentuk data mentah (raw data) dan memiliki kesalahan geometrik sehingga perlu dikoreksi secara geometrik ke dalam sistem koordinat bumi.

Pemotongan data citra dilakukan untuk membatasi citra yang akan dianalisis hanya pada daerah penelitian. Pemotongan citra dapat dilakukan berdasarkan koordinat, jumlah piksel atau hasil perbesaran (zooming) daerah. Penajaman band citra menggunakan komposit band Red-GreenBlue (RGB) 123. Pita ini digunakan karena ketiga pita tersebut paling sesuai untuk mendeteksi perubahan garis pantai. Setelah dilakukan penajaman citra kemudian dilakukan digitasi citra untuk mendapatkan keakuratan garis pantai.

Koreksi terhadap pasang surut sangat penting dilakukan untuk menghilangkan genangan air karena pengaruh pasang surut terhadap perekaman citra. Koreksi garis pantai terhadap pasang surut dilakukan dengan beberapa cara yakni menentukan kemiringan dasar pantai, menentukan koreksi garis pantai citra terhadap mean sea level (MSL).
Kemiringan dasar pantai diperoleh dengan mengetahui nilai kedalaman $(d)$ dan jarak mendatar $(m)$ dari garis pantai sampai kedalaman $d$ (Figure 2).

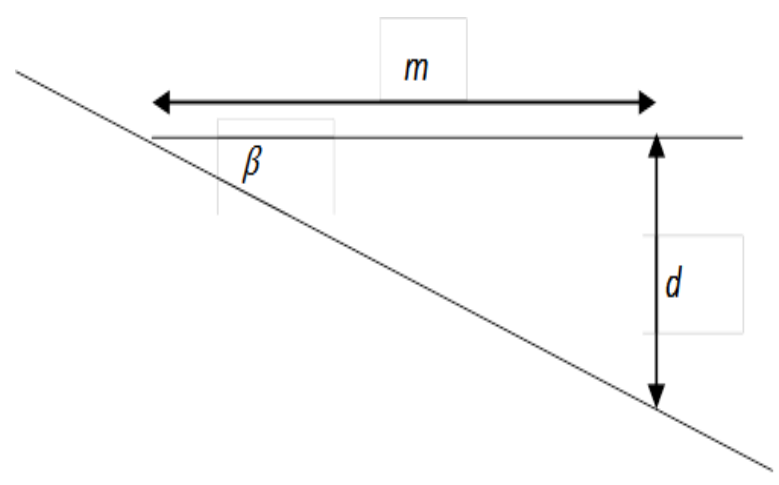

Figure 2. The schematic figure to calculate the slope of seabed in coastal waters.

Berdasarkan Figure 2 diperoleh persamaan kemiringan dasar pantai, yakni:

$\operatorname{Tan} \beta=\frac{d}{m}$

Koreksi garis pantai citra terhadap muka laut rata-rata (MSL) dilakukan dengan mengetahui selisih posisi muka air $(\eta)$ pada saat perekaman citra terhadap MSL (Figure 3). MSL diperoleh dari konstanta-konstanta pasut dari prediksi PUSHIDROSAL, sehingga jarak pergeseran garis pantai $(r)$ diperoleh melalui persamaan:

$r=\frac{(n)}{\tan \beta}$

Jika perekaman citra dilakukan pada saat air laut pasang maka garis pantai digeser ke arah laut sejauh $r$, sebaliknya jika air laut surut maka garis pantai digeser ke arah darat sejauh $r$.

Proses terakhir yaitu tumpang-susun, dimana proses ini dilakukan untuk melihat perubahan garis pantai yang terjadi di lokasi penelitian dengan menghitung nilai abrasi dan akresi. Untuk melihat perubahan garis pantai (erosi/akresi) secara jelas maka pantai 
wilayah kajian dibagi ke dalam 19 sel untuk perhitungan perubahan garis pantainya. Jika garis pantai tahun 2016 bergeser lebih jauh ke arah laut dibandingkan dengan garis pantai tahun 2003, maka lokasi sel tersebut ditentukan terjadi akresi, dan sebaliknya, terjadi abrasi.

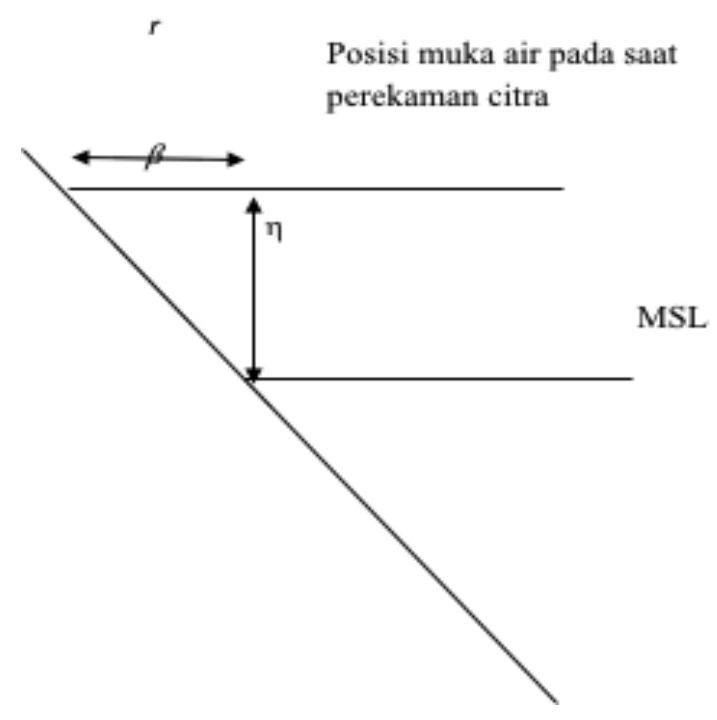

Figure 3. Schematic figure of the position of sea surface height at the time of satellite imagery acquisition.

\section{HASIL DAN PEMBAHASAN}

\subsection{Koreksi Citra Landsat}

Koreksi citra Landsat dilakukan dengan penajaman band menggunakan komposit band Red-Green-Blue (RGB) 123 sehingga menghasilkan citra dengan jelas batasan antara air dan tanah seperti Figure 4 bagian (a dan b), kemudian dilakukan proses digitasi secara visual interpretasi garis pantai seperti yang terlihat pada Figure 4 bagian (c). Arief et al. (2011), menjelaskan bahwa untuk mengetahui apakah suatu wilayah terjadi proses abrasi maupun akresi dapat diketahui dengan cara mengintegrasikan dua citra hasil digitasi garis pantai dari tahun yang berbeda. Pada citra Landsat 7 tanggal perekaman 16 Mei 2003 10:23:14 WITA didapatkan pada ketinggian elevasi muka laut $203.02 \mathrm{~cm}$ atau pada saat kondisi pasang.
Pada citra Landsat 8 dengan tanggal perekaman 9 Oktober 2016 10:28:47 WITA didapatkan pada ketinggian $204.82 \mathrm{~cm}$.

Hasil koreksi garis pantai citra tahun 2003 dan tahun 2016 (Figure 5), terlihat dengan jelas bahwa garis pantai sebelum dan setelah terkoreksi dengan MSL garis pantai bergeser, dimana garis pantai terkoreksi bergeser kearah laut dibandingkan dengan belum dikoreksi. Hal ini terjadi karena perekaman citra pada saat pasang dan juga kemiringan dasar pantai yang landai sehingga garis pantai akan semakin maju ke arah laut. Winarso et al. (2010) menjelaskan jika garis pantai yang dihasilkan citra adalah garis pantai saat pasang tinggi, ada perbedaan antara garis pantai dengan garis air rendah (chart datum) yang mana garis pantai adalah kedudukan rata-rata air tinggi sementara garis air rendah adalah pada saat air rendah atau dalam peta batimetri sebagai garis surutan 0 (low water line). Perubahan yang dihasilkan pada penampilan garis pantai, menurut Viles \& Spencer (2014) tidak hanya berlangsung dalam kurun waktu yang relatif pendek (skala menit atau jam). Pantai maju dapat disebabkan oleh pengangkatan pantai karena deposisi (akresi), sedangkan pantai mundur disebabkan oleh pantai tenggelam karena erosi.

\subsection{Analisis Perubahan Garis Pantai}

Layout pemetaan perubahan garis pantai dibagi menjadi 19 sel agar dapat dianalisis dengan jelas wilayah yang mengalami perubahan garis pantai (Figure 6). Berdasarkan Table 1 dan Figure 6, keseluruhan wilayah pesisir Pantai Barat Kabupaten Tanah Laut dan sekitarnya mengalami perubahan garis pantai baik berupa abrasi maupun akresi. Hasil analisis perubahan garis pantai secara dominan telah mengalami akresi sepanjang 168,85 km dengan luas 2371,23 ha, dibandingkan yang telah mengalami abrasi hanya sepanjang 9,28 $\mathrm{km}$ dengan luas 28,02 ha. Hal ini diduga disebabkan karena pensuplai utama sedimentasi sangat besar oleh muara Sungai 

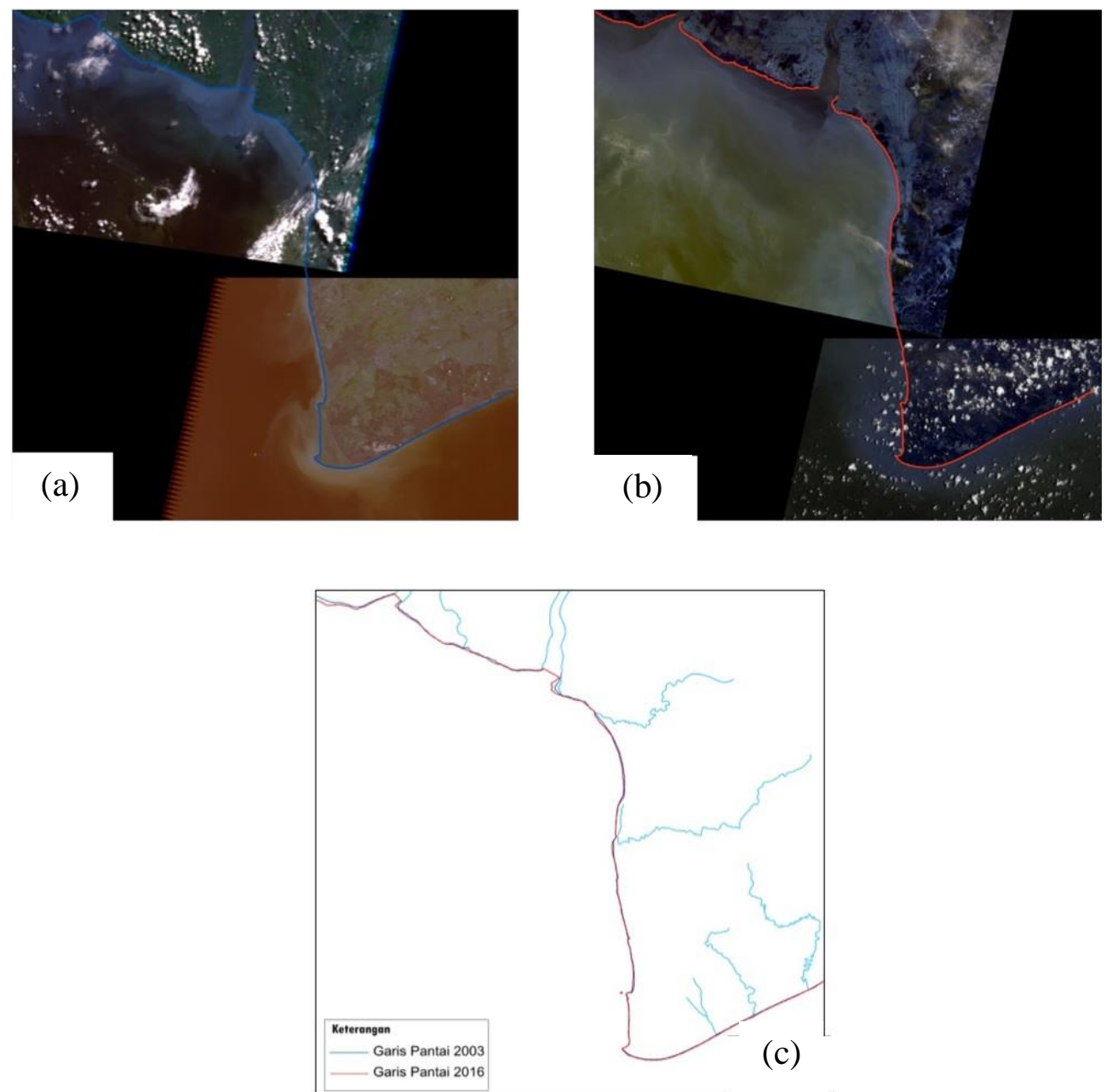

Figure 4. Band ratio analysis of shoreline extraction and digitized shoreline using Landsat satellite imagery; (a) imagery in 2003; (b) imagery in 2016; (c) combined both Landsat imageries (2003 and 2016) before the tide and mean sea level corrections.
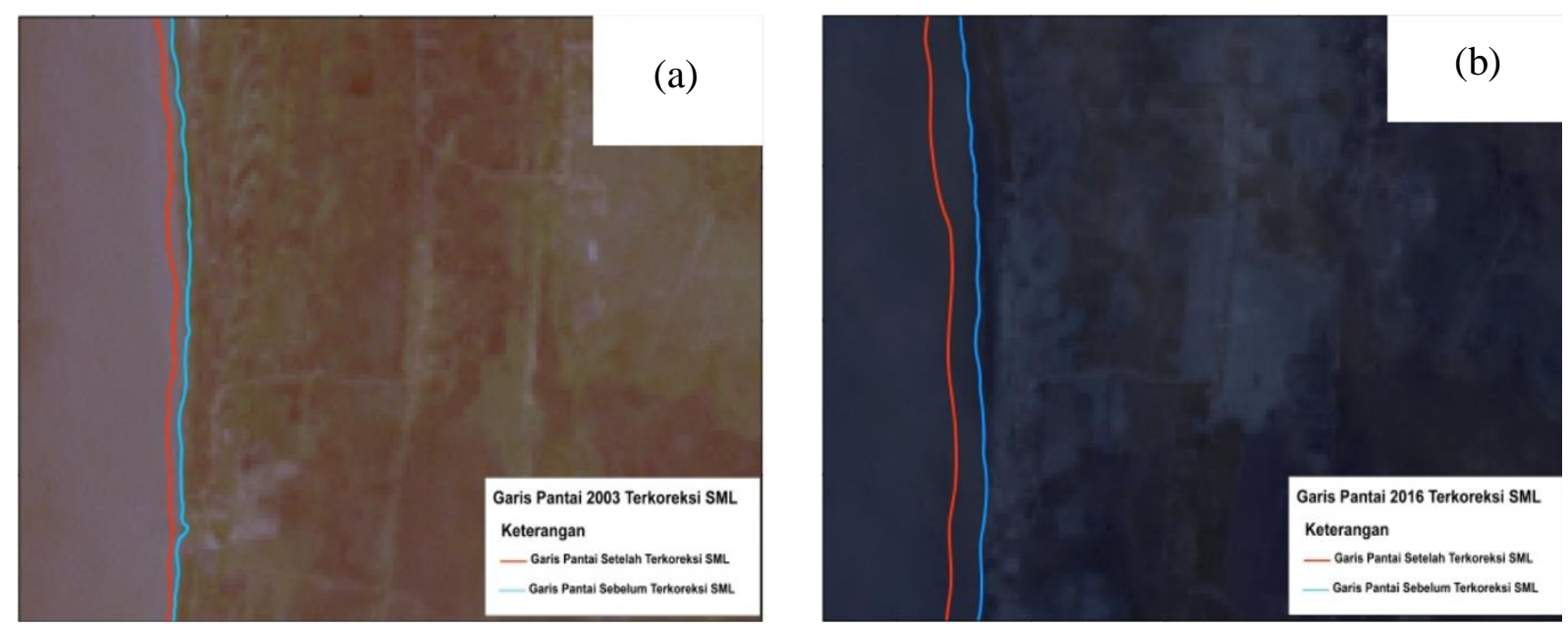

Figure 5. Landsat imageries after shorelines correction to mean sea level (MSL); (a) imagery in 2003; (b) imagery in 2016. 
Barito dan Sungai Kapuas serta muara-muara sungai kecil lainnya. Menurut Sugeng (2009) laju sedimentasi yang tinggi dari Sungai Barito menyebabkan tingkat pengendapan lumpur pada ambang batas luarnya mencapai $6,36 \mathrm{~cm} /$ bulan. Pergeseran perubahan garis pantai di wilayah studi, hampir sama dengan penelitian yang telah dilakukan Halim et al. (2011) di wilayah pesisir Kecamatan Soropia, serta hasil penelitian Handjojo et al. (2015) di Kelurahan Terusan Kecamatan Mempawah Hilir Kabupaten Mempawah, mengenai perubahan garis pantai yang mengalami perubahan garis pantai dominan akresi yang dipengaruhi oleh daerah aliran sungai. Majunya garis pantai disebabkan sedimentasi yang relatif cepat di suatu wilayah pantai dekat muara sungai dan sedimen yang diendapkan secara terus menerus membentuk daratan baru dan menambah luas daratan yang telah ada (Muryani, 2010). Mundurnya garis pantai disebabkan adanya proses erosi oleh energi gelombang (Arief et al., 2011).
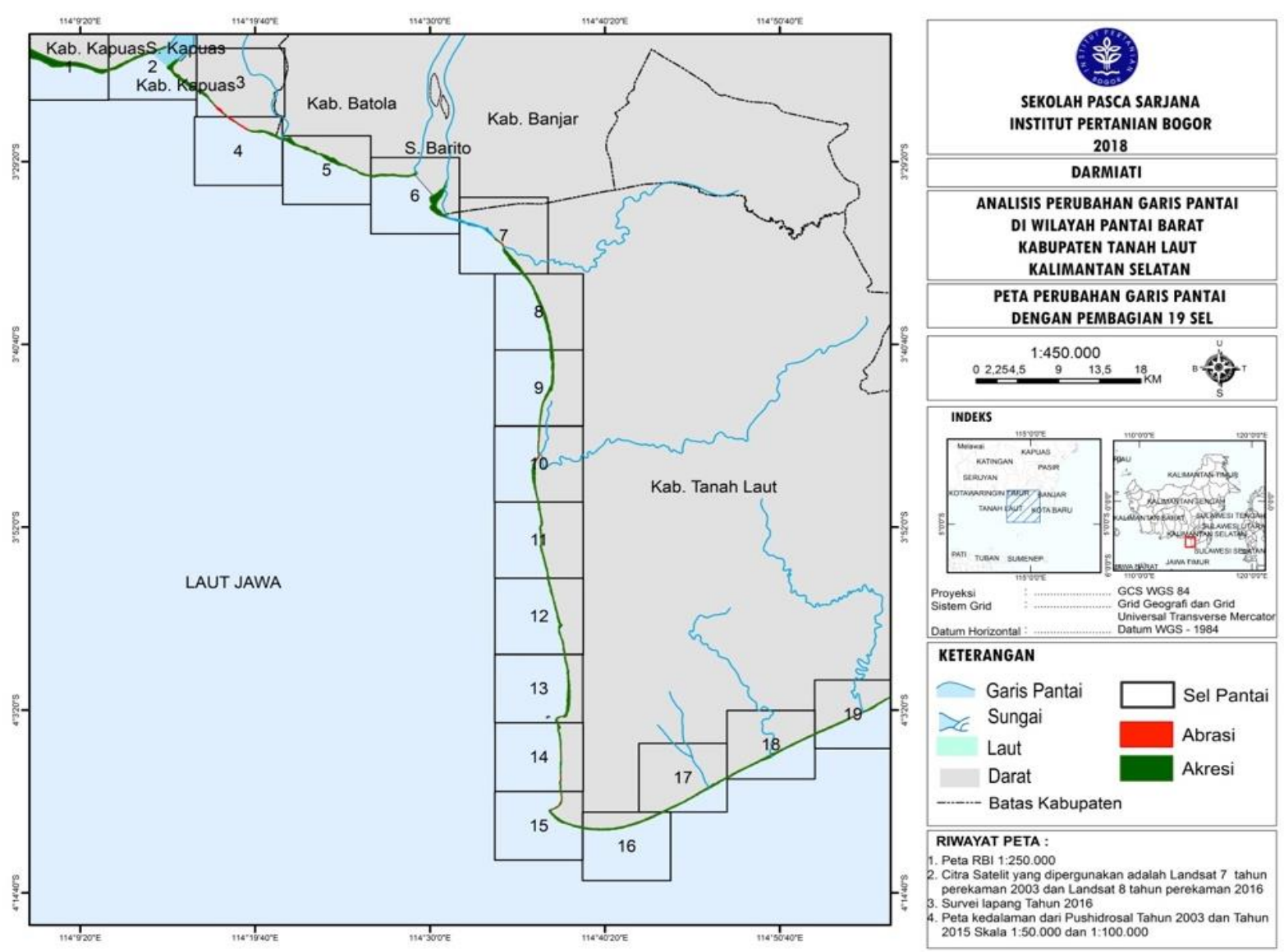

Figure 6. Schematic map for calculating shoreline changes by dividing the coastal area into 19 cells.

Table 1. Analysis of shoreline changes in 2003 and 2016.

\begin{tabular}{cccc}
\hline \multirow{2}{*}{ Beach conditions } & \multicolumn{3}{c}{ Change in coastline } \\
\cline { 2 - 4 } & Area $(\mathrm{ha})$ & Lenght $(\mathrm{km})$ & Percentage $(\%)$ \\
\hline Abrasion & 28.02 & 9.28 & 5.21 \\
Accretion & 2371.23 & 168.85 & 94.79 \\
\hline Total & 2399.25 & 178.13 & 100 \\
\hline
\end{tabular}


Majunya garis pantai biasanya berdampak positif karena pantai mengalami penambahan wilayah, tetapi untuk daerah pantai yang dipengaruhi oleh muara sungai akan terganggu karena terjadi pendangkalan yang menyebabkan terganggunya alur transportasi sungai. Terganggunya keseimbangan pantai seperti proses erosi tidak hanya karena terjadinya abrasi, tetapi juga erat kaitannya dengan proses akresi yaitu sedimentasi pantai yang terjadi bila jumlah sedimen yang diendapkan lebih besar daripada kekuatan arus laut untuk mengangkut sedimen tersebut sehingga daratan pantai akan bertambah dan terjadi pendangkalan (Diposaptono \& Budiman, 2008). Kondisi cuaca yang sering tidak menentu dan saat musim barat, ketika terjadi pasang tertinggi, limpasan air telah memasuki kawasan pemukiman. Jika bersamaan dengan curah hujan yang tinggi, maka akan mengakibatkan genangan yang serius.

Berdasarkan pada Table 2, sel 1, 2, 5, $6,8,9,11,12$ dan $16-18$, hanya mengalami kondisi akresi tanpa abrasi. Hal ini diduga disebabkan karena partikel yang terdistribusi dari muara-muara sungai ke arah laut jauh lebih besar. Dari hasil observasi lapangan, bentuk partikel atau material pantai di wilayah studi memang lebih dominan pantai berlumpur dan pantai berpasir. Masukan sedimen dari darat yang dibawa dari sungai menuju ke muara sungai hingga ke laut. Pantai lumpur yang memiliki sedimen dengan ukuran yang lebih halus akan mengendap dan tersebar jauh dari pantai. proses pengendapan terjadi karena adanya tenaga arus yang dibangkitkan dari pasang surut dan gelombang. Davis (1984) menyatakan bahwa arus sungai yang memasuki air laut dalam kondisi pasang akan

Table 2. Analysis of shoreline changes in Tanah Laut Regency (2003 and 2016) at each cell.

\begin{tabular}{|c|c|c|c|c|c|c|c|}
\hline \multirow[t]{2}{*}{ Cell } & \multicolumn{2}{|c|}{ Lenght $(K m)$} & \multirow[t]{2}{*}{ Total } & \multicolumn{2}{|c|}{$\begin{array}{l}\text { Beach conditions } \\
\text { (ha) }\end{array}$} & \multirow[t]{2}{*}{ Total } & \multirow[t]{2}{*}{ Percentage \% } \\
\hline & Abrasion & Accretion & & Abrasion & Accretion & & \\
\hline 1 & & 9.21 & 9.21 & & 516.08 & 516.08 & 21.51 \\
\hline 2 & & 10.82 & 10.82 & & 199.72 & 199.72 & 8.32 \\
\hline 3 & 1.10 & 5.60 & 6.69 & 10.05 & 109.32 & 119.36 & 4.98 \\
\hline 4 & 2.88 & 6.31 & 9.19 & 10.57 & 105.64 & 116.21 & 4.84 \\
\hline 5 & & 9.46 & 9.46 & & 146.63 & 146.63 & 6.11 \\
\hline 6 & & 10.96 & 10.96 & & 71.66 & 71.66 & 2.99 \\
\hline 7 & 0.64 & 11.02 & 11.66 & 1.47 & 189.31 & 190.77 & 7.95 \\
\hline 8 & & 9.02 & 9.02 & & 161.66 & 161.66 & 6.74 \\
\hline 9 & & 8.76 & 8.76 & & 114.42 & 114.42 & 4.77 \\
\hline 10 & 1.11 & 7.73 & 8.84 & 3.56 & 80.96 & 84.51 & 3.52 \\
\hline 11 & & 8.76 & 8.76 & & 54.78 & 54.78 & 2.28 \\
\hline 12 & & 8.88 & 8.88 & & 65.13 & 65.13 & 2.71 \\
\hline 13 & 1.53 & 9.27 & 10.81 & 0.02 & 121.44 & 121.46 & 5.06 \\
\hline 14 & 0.84 & 7.80 & 8.64 & 1.11 & 34.12 & 35.22 & 1.47 \\
\hline 15 & 0.60 & 7.09 & 7.69 & 0.41 & 64.74 & 65.15 & 2.72 \\
\hline 16 & & 9.10 & 9.10 & & 90.58 & 90.58 & 3.78 \\
\hline 17 & & 9.99 & 9.99 & & 86.06 & 86.06 & 3.59 \\
\hline 18 & & 9.81 & 9.81 & & 98.81 & 98.81 & 4.12 \\
\hline 19 & 0.57 & 9.25 & 9.82 & 0.85 & 60.18 & 61.03 & 2.54 \\
\hline Total & 9.28 & 168.85 & 178.13 & 28.02 & 2371.23 & 2399.25 & 100 \\
\hline
\end{tabular}


mengalami perlambatan yang mengakibatkan kemampuan pengangkutan material berkurang sehingga material tersebut mengendap, sebaliknya dalam kondisi surut sedimen dari sungai akan terbawa kearah laut. Kenaikan muka air laut juga menyebabkan perubahan pola sedimentasi dan pendangkalan di muara sungai yang dapat mengganggu akses keluar masuknya perahu yang digunakan nelayan untuk melaut (Diposaptono et al., 2009). Kemiringan yang landai dan perairan yang cenderung dangkal menyebabkan resuspensi material yang dipengaruhi oleh angin, gelombang dan pasang surut, serta adanya perluasan dan perubahan penggunahan lahan yang terjadi di wilayah studi. Hammar-Klose et al. (2003) menjelaskan pantai yang landai lebih rentan mengalami perpindahan partikel sedimen sebagai komponen utama pembentuk profil pantai dibandingkan dengan pantai yang lebih curam.

Berdasarkan hasil observasi lapangan, pada wilayah studi terjadi perubahan penggunaan lahan sebagai kebun sawit dan tambang serta pembukaan lahan yang diduga menyebabkan sedimentasi tinggi dari wilayah hulu sungai ketika curah hujan tinggi. Hal ini sama dengan penjelasan Suhana et al. (2016) bahwa akresi disebabkan oleh sedimentasi yang terjadi dipengaruhi oleh aktivitas manusia berupa penimbunan dan perluasan kawasan laut untuk dijadikan kawasan pemukiman masyarakat.

Perubahan garis pantai pada kondisi abrasi dominan terjadi di wilayah sel 3 dan sel 4 dengan masing-masing luas sebesar 10,05 ha sepanjang $1,10 \mathrm{~km}$ dan 10,57 ha sepanjang $2.88 \mathrm{~km}$. Kedua sel tersebut juga mengalami akresi yang masing-masing sebesar 109,32 ha sepanjang 5,60 km, dan 105,64 ha sepanjang $6,31 \mathrm{~km}$. Wilayah di kedua sel ini juga masih dipengaruhi muara Sungai Barito dan Kapuas dengan kondisi pantai berlumpur. Kondisi akresi di sel 3 dan 4 diduga berkaitan dengan bentuk geomorfologi pantai berupa tonjolan di sepanjang sel tersebut, sehingga mendapat hempasan gelombang laut lebih intensif dalam periode musim barat. Pada kondisi akresi yang dominan terjadi di wilayah sel 1 dan sel 2 dengan masing-masing luas sebesar 516,08 ha sepanjang 9,21 $\mathrm{km}$ dan 199,72 ha sepanjang $10,82 \mathrm{~km}$, tetapi tidak mengalami abrasi.

Perubahan akresi/abrasi di sel 10 dan sel 7 memiliki luasan sebesar 3,56 ha sepanjang $1,11 \mathrm{~km}$ dan 1,47 ha sepanjang $0,64 \mathrm{~km}$. Pada kedua sel tersebut juga mengalami akresi yang masing-masing memiliki luasan sebesar 80.96 ha sepanjang 7,73 km dan 189,31 ha sepanjang 11,02 km. Kondisi pantai pada sel 10 yaitu didominasi pantai campuran dan pantai berpasir, dimana wilayah pada sel ini terdapat kawasan pemukiman nelayan yang sangat dekat dengan garis pantai, sehingga rentan terkena abrasi. Pada sel 7 termasuk daerah rataan pasang surut dengan kondisi pantai berlumpur sehingga banyak ditumbuhi oleh tanaman bakau sebagai garis pantai. kondisi garis pantai yang mengalamai abrasi dengan rusaknya bakau akibat gelombang pasang dan perubahan lahan sebagai lahan tambak, sehingga mengurangi tutupan bakau. Kerusakan bakau mempengaruhi perubahan garis pantai (Soraya et al., 2012). Neraca abrasi-akresi di sel 13 hingga 15 dan 19 juga mengalami akresi dan abrasi. Seluruh sel mempunyai kondisi pantai yang berpasir jauh dari pengaruh proses Sungai Barito, akan tetapi abrasi terjadi karena proses kenaikan muka air laut dan gelombang.

Berdasarkan hasil analisis neraca abrasi/akresi di 19 sel, maka wilayah yang dominan mengalami akresi terjadi di sel 1 sepanjang 18,157 km dengan luas 433,674 ha, diikuti wilayah pada sel 7 dan 2 yang masing-masing dengan panjang perubahan garis pantai $31,839 \mathrm{~km}$ dan 22,148 km dengan luas 308,683 ha dan 203,110 ha. Wilayah yang dominan mengalami abrasi yaitu terjadi di sel 3 sepanjang $3,550 \mathrm{~km}$ dengan luas 12,795 ha (Figure 7). 

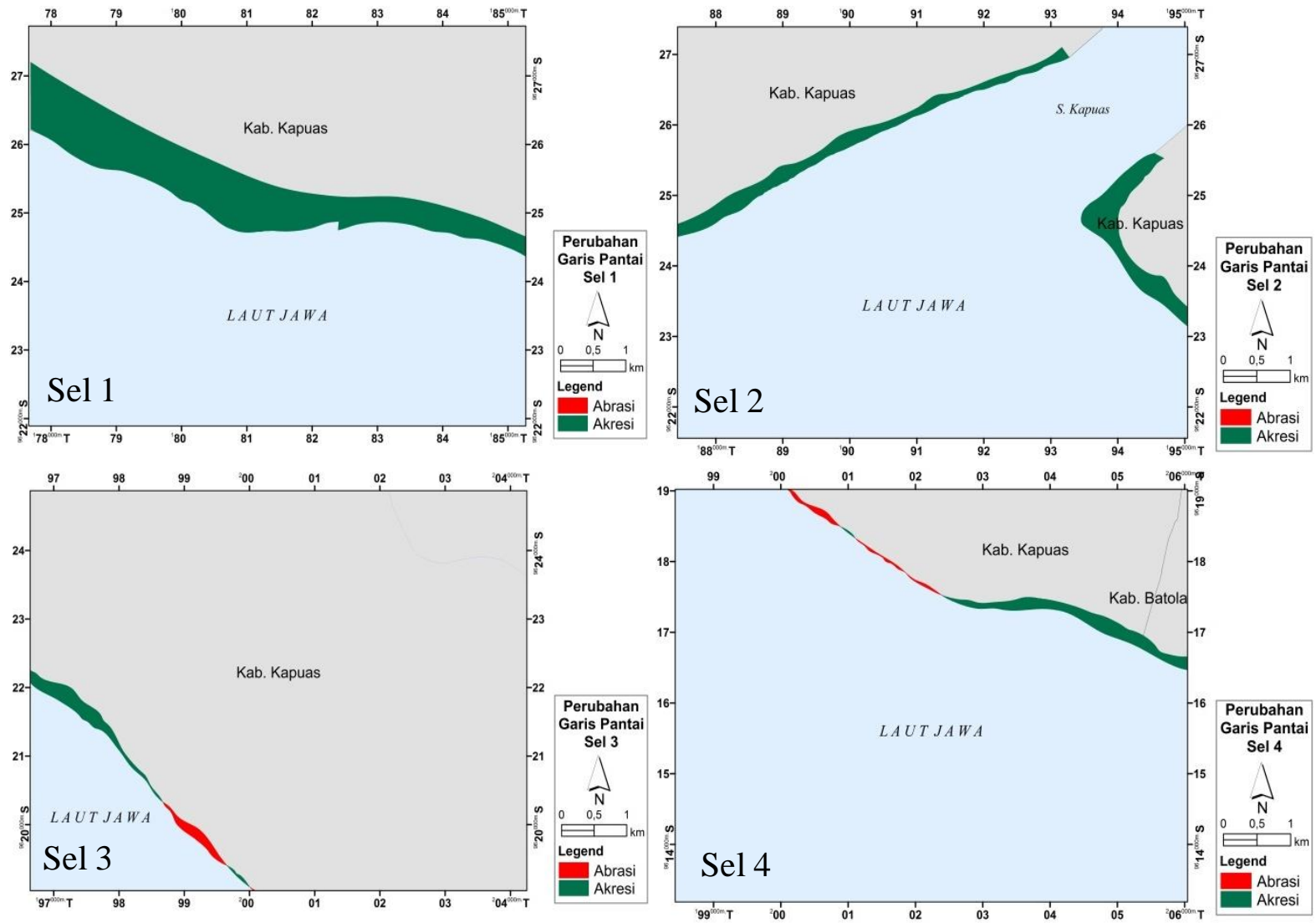

Figure 7. High shoreline changes in the study area. Those are from cell 1 to cell 4.

\section{KESIMPULAN}

Perubahan garis pantai yang terjadi di wilayah Pantai Barat Kabupaten Tanah Laut dari analisis citra Landsat tahun 2003 dan 2016 berupa abrasi dan akresi. Faktor yang menimbulkan abrasi utamanya adalah gelombang laut yang terjadi dalam periode musim Barat, sedangkan faktor akresi adalah suplai sedimen dari limpasan sistem daerah aliran sungai Barito. Secara keseluruhan garis pantai Kabupaten Tanah Laut mengalami akresi sepanjang 168,85 km dengan luas 2371,23 ha dan abrasi hanya sepanjang 9,28 km dengan luas 28,02 ha. Dengan demikian, dapat disimpulkan bahwa garis pantai di sepanjang Pantai Barat Kabupaten Tanah Laut lebih banyak terjadi akresi dibandingkan dengan abrasi.

\section{UCAPAN TERIMA KASIH}

Penulis menghaturkan terima kasih kepada para Penelaah (Reviewers) atas koreksi dan masukannya untuk penyempurnaan naskah makalah ini. Data citra Landsat diakses dari http://earthexplorer.usgs.gov. Terima kasih juga disampaikan kepada para asisten yang telah membantu dalam survei lapangan di pesisir pantai barat Kabupaten Tanah Laut Kalimantan Selatan.

\section{DAFTAR PUSTAKA}

Arief, M., G. Winarso, \& T. Prayogo. 2011. Kajian perubahan garis pantai menggunakan data satelit Landsat di Kabupaten Kendal. J. Penginderaan Jauh dan Pengolahan Data Citra Digital, 8(1): 71-70. 
http://jurnal.lapan.go.id/index.php/jur nal_inderaja/article/view/1614

Davis, F.D. 1984. A technology acceptance model for empirically testing new end-user information systems: theory and results (doctoral dissertation). Massachusetts Institute of Technology. Cambridge. 291 p.

Diposaptono, S. \& Budiman. 2008. Hidup akrab dengan gempa dan tsunami. Buku Ilmiah Populer. Bogor. 383 p.

Diposaptono, S., Budiman, \& F. Agung. 2009. Menyiasati perubahan iklim di wilayah pesisir dan pulau-pulau kecil. Buku Ilmiah Populer. Bogor. 359 p.

Halim, Halili, \& L.O.A. Afu. 2016. Studi perubahan garis pantai dengan pendekatan penginderaan jauh di wilayah Pesisir Kecamatan Soropia. J. Ilmu Kelautan, 1(1): 2431 .

Hammar-Klose, E.S., E.A. Pendleton, E.R. Thieler, \& S.J. Williams. 2003. Coastal vulnerability assessment of Cape Cod National Seashore (CACO) to sea-level rise. USGS Report. $23 \mathrm{p}$.

Handjojo, Z.O., T.F. Manurung, \& K.P. Utomo. 2015. Perubahan garis pantai akibat kerusakan hutan mangrove di Kelurahan Terusan Kecamatan Mempawah Hilir Kabupaten Mempawah. J. Mahasiswa Teknik Lingkungan, 1(1): 1-10.

Iriadenta, A. 2013. Degradation of coastal swamp ecosystem in subdistrict of Jorong Tanah Laut Regency South Kalimantan. Fish Scientiae, 3(6): 157-170. http://doi.org/10.20527/fs.v3i6.1145

Kasim, F. 2012. Pendekatan beberapa metode dalam monitoring perubahan garis pantai menggunakan dataset penginderaan jauh Landsat dan SIG. J. Ilmiah Agropolitan, 5(1): 620635.

Mills, J.P., S.J. Buckley, H.L. Mitchell, P. J. Clarke, \& S.J. Edwards. 2005. A geomatics data integration technique for coastal change monitoring. $J$. Earth Surface Processes and Landforms, 30(6): 651-664. http://doi.org/10.1002/esp.1165

Muryani, C. 2010. Analisis perubahan garis pantai menggunakan SIG serta dampaknya terhadap kehidupan masyarakat di sekitar Muara Sungai Rejoso Kabupaten Pasuruan. J. Forum Geografi, 24(2): 173-182. http://doi.org/10.23917/forgeo.v24i2. 5024

Opa, E.T. 2011. Perubahan garis pantai Desa Bentenan Kecamatan Pusomaen, Minahasa Tenggara. J. Perikanan dan Kelautan Tropis, 7(3): 109-114. https://doi.org/10.35800/jpkt.7.3.2011 .187

Sardiyatmo, S., S. Supriharyono, \& A. Hartoko. 2013. Dampak dinamika garis pantai menggunakan citra satelit multi temporal Pantai Semarang Provinsi Jawa Tengah. J. Saintek Perikanan, 8(2): 33-37.

http://doi.org/10.14710/ijfst.8.2.33-37

Soraya, D., O. Suhara, \& A. Taofiqurohman. 2012. Perubahan garis pantai akibat kerusakan hutan mangrove di Kecamatan Blanakan dan Kecamatan Legonkulon, Kabupaten Subang. J. Perikanan Kelautan, 3(4): 355-364.

Sudarsono, B. 2011. Inventarisasi perubahan wilayah pantai dengan metode penginderaan jauh (studi kasus Kota Semarang). J. Teknik, 32(2): 163-170. http://doi.org/10.14710/teknik.v32i2.1 699

Sugeng, S. 2009. Pemeliharaan alur pelayaran di Sungai Barito. Kapal, 6(2): 142-150. https://doi.org/10.14710/kpl.v6i2.272 7

Suhana, M.P., I.W. Nurjaya, \& N.M. Natih. 2016. Analisis kerentanan Pantai Timur Pulau Bintan, Provinsi Kepulauan Riau menggunakan digital shoreline analysis system dan metode coastal vulnerability index. J. 
Teknologi Perikanan dan Kelautan, 7(1): 21-38. http://doi.org/10.24319/jtpk.7.21-38

Viles, H. \& T. Spencer. 2014. Coastal problems: geomorphology, ecology and society at the coast. Routledge. London. 360 p.

Winarso, G., H. Joko, \& S. Arifin. 2010. Kajian penggunaan data inderaja untuk pemetaan garis pantai (studi kasus Pantai Utara Jakarta). $J$. Penginderaan Jauh dan Pengolahan Data Citra Digital, 6: 65-72.

http://jurnal.lapan.go.id/index.php/jur nal_inderaja/article/view/1187

Received : :09 September 2019

Reviewed : :17 October 2019

Accepted :05 April 2020 